\title{
Sosialisasi Pemanfaatan Air Hujan dengan Pembuatan Sumur Resapan Untuk Penanggulangi Banjir/Genangan dan Konservasi Air Tanah di SMP Negeri 8 Menteng Jakarta Pusat
}

\author{
Endah Lestari ${ }^{1}$; Desi Putri ${ }^{2}$; Irma Wirantina K. ${ }^{3}$; Rr. Mekar Ageng Kinasti ${ }^{4}$; \\ Muhammad Sofyan $^{5}$; Ranti Hidayawanti ${ }^{6}$; Iriansyah BM. Sangadji ${ }^{7}$

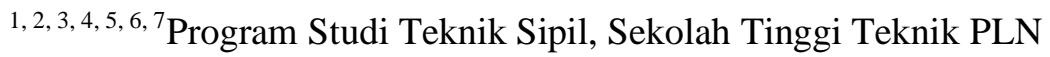 \\ endahlestari@sttpln.ac.id
}

\begin{abstract}
ABSTRAK
Dalam beberapa tahun terakhir ini banjir dan kekeringan terjadi diberbagai tempat di Indonesia. Pulau Jawa termasuk salah satu wilayah kepulauan yang sering mengalami banjir. Pada musim hujan bencana banjir menyebabkan beberapa kota besar terendam. Jakarta sempat beberapa kali terkena bencana banjir yang cukup parah. Kejadian banjir yang terjadi di tahun 2007 menyebabkan kurang lebih 60\% wilayah DKI terendam air dengan kedalaman mencapai lebih dari 5 meter. Mitra PKM merupakan bangunan sekolah menengah pertama negeri yang terletak di daerah Menteng, Jakarta Pusat. Wilayah Mitra beberapa tahun terakhir mengalami bencana banjir, hal tersebut cukup mengganggu proses belajar mengajar di wilayah Mitra. Krisis air bersih juga terjadi di wilayah Mitra, hal ini diakibatkan lokasi Mitra yang cukup berdekatan dengan bangunan-bangunan perkantoran yang memiliki kebutuhan air bersih yang cukup besar.

Curah hujan rata-rata di Indonesia adalah 2779 mm per tahun, di Jakarta sekitar 2500 mm per tahun, dengan jumlah air hari hujan 180 hari/tahun. Dengan rata-rata curah hujan yang cukup besar merupakan potensi sumber daya air yang dapat dimanfaatkan secara maksimal. Dengan potensi sumber daya air yang ada maka diperlukan adanya usaha-usaha untuk memanfaatkan sumber daya air khususnya air hujan, salah satunya adalah dengan cara membuat teknik peresapan air ke dalam tanah berupa sumur resapan. Melalui kegiatan sosialisasi ini, diharapkan dapat mengembangkan kesadaran masyarakat mengenai bagaimana cara menanggulangi banjir pada skala kecil yaitu pada tingkat rumah tangga sampai ke tingkat yang lebih luas lagi, sekolah, bangunan-bangunan perkantoran, dan lain-lain dengan menggunakan teknologi sumur resapan dalam menangani banjir dan konservasi air tanah.
\end{abstract}

Kata kunci: banjir, kekeringan, sumber daya air, sumur resapan, konservasi air tanah.

\begin{abstract}
In recent years floods and droughts have occurred in various places in Indonesia. Java is one of the islands that often experiences flooding. During the rainy season floods cause several major cities to be submerged. Jakarta was hit several times by severe flooding. Flood events that occurred in 2007 caused approximately $60 \%$ of the DKI area to be submerged by a depth of more than 5 meters. PKM Partners is a public junior high school building located in Menteng, Central Jakarta. The Mitra area in the last few years has experienced a flood, it is quite disturbing the teaching and learning process in the Mitra area. The clean water crisis also occurs in the Mitra area, this is due to the location of the Mitra which is quite close to office buildings that have large enough water needs.

The average rainfall in Indonesia is $2779 \mathrm{~mm}$ per year, in Jakarta around $2500 \mathrm{~mm}$ per year, with 180 days / year of rainy days. With a large enough rainfall average is the potential of water resources that can be utilized optimally. With the potential of existing water resources, it is necessary to have efforts to utilize water resources, especially rainwater, one of which is by making water infiltration techniques into the ground in the form of infiltration wells. Through this outreach activity, it is hoped that it can develop public awareness on how to tackle flooding on a small scale, namely at the household level to a wider level, schools, office buildings, etc. by using infiltration well technology in handling floods. and groundwater conservation.
\end{abstract}


Keywords: floods, droughts, water resources, infiltration wells, groundwater conservation

\section{PENDAHULUAN}

\subsection{Analisis Situasi}

Dalam beberapa dekade terakhir ini banjir dan kekeringan terjadi di berbagai tempat di Indonesia. Dampak yang diakibatkan oleh kekeringan adalah jutaan hektar pertanian di Jawa dan luar Jawa terancam gagal panen, sementara itu pada musim hujan bencana banjir menyebabkan beberapa kota besar terendam. Jakarta sempat beberapa kali terkena bencana banjir yang cukup parah. Kejadian banjir yang terjadi di tahun 2007 menyebabkan kurang lebih 60\% wilayah DKI terendam air dengan kedalaman mencapai $5 \mathrm{~m}$ lebih. Selain sistem drainase yang buruk, banjir berawal dari dari hujan yang lebat selama 2 hari ditambah dengan banyaknya volume air dari 13 sungai yang melintasi Jakarta yang tidak bisa tertampung lagi. Banjir di tahun 2013 yang menyebabkan 20 korban meninggal dunia dan 33.500 orang mengungsi. Diperkirakan banjir tersebut menyebabkan kerugian hingga Rp 20 triliun.

Daerah imbuhan (recharge area) karena perkembangan penduduk yang besar-besaran dan pertumbuhan ekonomi terjadi alih fungsi lahan menjadi lahan permukiman, industri, dan lain-lain yang mengakibatkan terjadinya penurunan resapan air. Selain karena peningkatan kebutuhan akan air bersih juga menyebabkan penurunan ketersediaan air tanah. Perubahan fungsi lahan memberikan dampak salah satunya yaitu menyebabkan peningkatan aliran permukaan (run-off) yang menyebabkan terjadi peningkatan potensi bencana banjir. [1]

Faktor perubahan tata guna lahan dari daerah yang belum dibangun menjadi daerah yang dibangun dapat mempengaruhi aliran air sungai. Dengan adanya perubahan tata guna lahan debit air limpasan akan lebih besar yang akan berpengaruh pada debit aliran sungai dan juga kualitas air sungai itu sendiri. [2]

Perubahan penggunaan lahan dari daerah pertanian/perkebunan/hutan/rawa menjadi daerah pemukiman akan menyebabkan berkurangnya daerah infiltrasi alami. Sehingga apabila hujan turun pada daerah tersebut maka air hujan akan dengan cepat berubah menjadi aliran permukaan. Air hujan yang telah berubah menjadi aliran permukaan tersebut akan semakin banyak dan segera mengalir ke tempat yang lebih rendah untuk seterusnya masuk kedalam sungai menjadi aliran sungai. Keadaan semacam inilah yang sering kali menimbulkan banjir bahkan oleh hujan yang kecil sekalipun. [3]

Demikian pula halnya dengan Jakarta, sebagai akibat dari perubahan penggunaan lahan telah menyebabkan berkurangnya lahan yang sebelumnya merupakan zone infiltrasi alami. Perubahanperubahan yang menyebabkan zone infiltrasi menjadi berkurang antara lain: a. Lahan yang dipakai untuk bangunan. b. Lahan yang dipakai untuk jalan, c. Lahan yang diaspal/beton. d. Tubuh air (situ, danau alam, dan rawa alam) yang ditimbun.

Air merupakan sumber daya alam yang dikuasai oleh negara dan dimanfaatkan untuk kesejahteraan rakyat. Sumber daya air sangat dibutuhkan oleh setiap mahluk hidup demi kelangsungan hidupnya. Akan tetapi krisis air sedang melanda di berbagai benua di dunia, bahkan benua Asia yang mempunyai curah hujan yang cukup tinggi masih saja dilanda wabah kekeringan di beberapa negara, termasuk Indonesia. Oleh sebab itu pemanfaatan sumber daya air harus dilakukan secara bijak.

Menurut data Badan Geologi pada tahun 2009, eksplorasi air tanah telah mencapai angka 40\%. Angka ini menunjukkan tingkat eksplorasi air tanah berada dia atas ambang batas ekplorasi air tanah yang direkomendasikan yaitu di angka 20\%. Hal ini diperparah dengan kurangnya daerah resapan air di Jakarta dan sekitarnya. Eksploitasi air tanah yang berlebihan akan menyebabkan penurunan muka tanah (Land-Subsidence), Intrusi Air Laut, dan lain sebagainya. [2] 
Curah hujan rata-rata di Indonesia adalah $2779 \mathrm{~mm}$ per tahun, di Jakarta sekitar $2500 \mathrm{~mm}$ per tahun, dengan jumlah air hari hujan 180 hari/tahun. Jika dihitung maka intensitas hujan rata-rata adalah $0,01388 \mathrm{~mm} /$ hari-hujan. Dengan rata-rata curah hujan yang cukup besar maka diperlukan adanya usaha-usaha untuk memanfaatkan sumber daya air khususnya air hujan salah dengan membuat metode-metode peresapan air ke dalam tanah. Beberapa diantaranya adalah metode Sumur Resapan, Lubang Biopori, Kolam Konservasi, Kolam Retensi dan masih banyak lagi. [4]

Sumur resapan adalah suatu rekayasa teknik konservasi air tanah berupa bangunan yang dibuat menyerupai bentuk sumur gali dengan kedalaman tertentu yang berfungsi sebagai tempat untuk memasukkan air hujan yang jatuh di atas atap rumah atau wilayah kedap air untuk diresapkan ke dalam tanah. Saat hujan deras, kelebihan air hujan dialirkan dari tangki ke sumur resapan. Penggunaan sumur resapan akan memungkinkan pengurangan biaya untuk drainase air hujan. [5]

Keuntungan yang dapat diperoleh jika melakukan konservasi dengan menggunakan sumur resapan adalah: a. Mencegah intrusi air laut terutama didataran pantai. b. Mereduksi dimensi jaringan drainase, dapat sampai nol jika diperlukan. c. Menurunkan konsentrasi pencemaran air tanah. d. Mempertahankan tinggi muka air tanah. e. Mencegah penurunan kawasan atau land subsiden. $\mathrm{f}$. Melestarikan teknologi tradisionil sebagai budaya bangsa. g. Meningkatkan peran serta masyarakat dalam era pembangunan. h. Membudayakan pola pikir pelestarian lingkungan.

Beberapa peraturan yang terkait dengan pemanfaatan air hujan salah satunya adalah Peraturan Menteri Negara Lingkungan Hidup Nomor 12 Tahun 2009 tentang Pemanfaatan Air Hujan. Di dalam Permen tersebut di Pasal 1 dijelaskan definisi dari pemanfaatan air hujan, yaitu serangkaian kegiatan mengumpulkan, menggunakan, dan/atau meresapkan air hujan ke dalam tanah. Serangkaian kegiatan tersebut dapat berupa pembuatan Sumur Resapan, Kolam Pengumpul Air dan Lubang Resapan Biopori. [6]

Peraturan lain yang terkait dengan sumur resapan adalah adanya Peraturan Gubernur DKI Jakarta No. 20 Tahun 2013 tentang Sumur Resapan pasal 3 ayat 1 yaitu Kewajiban pembuatan sumur resapan bagi perorangan dan badan hukum ditujukan kepada: a. setiap pemilik dan bangunan gedung yang menutup permukaan tanah; dan b. setiap pemohon dari pengguna air tanah.

\subsection{Permasalahan Mitra}

Mitra masyarakat yang akan bekerjasama dalam melaksanakan Program Kemitraan masyarakat Jurusan Teknik Sipil ini adalah SMP Negeri 8 yang berlokasi di Kecamatan Menteng, Jakarta Pusat. SMPN 8 merupakan wadah akademik dalam mengelola generasi penerus bangsa secara intelektual yang sangat besar potensinya untuk memanfaatkan sumber daya air berupa air hujan sebagai metode penanggulangan banjir dan genangan melalui teknologi konservasi air tanah demi masa yang akan datang melalui sosialisasi yang akan diberikan.

Target peserta yang akan mengikuti acara sosialisasi adalah 20 (dua puluh) orang yang terdiri dari:

1. Seluruh civitas akademik SMP Negeri 8 yang berkenan hadir mengikuti acara sosialisasi pemanfaatan air hujan sebagai metode penanggulangan banjir/genangan dan teknologi konservasi air tanah.

2. Pengurus dan Anggota OSIS SMP Negeri 8

Daerah imbuhan (recharge area) karena perkembangan penduduk yang besar-besaran dan pertumbuhan ekonomi terjadi alih fungsi lahan menjadi lahan permukiman, industri, dan lain-lain yang mengakibatkan terjadinya penurunan resapan air. Selain karena peningkatan kebutuhan akan air bersih juga menyebabkan penurunan ketersediaan air tanah. Perubahan fungsi lahan memberikan 
dampak salah satunya yaitu menyebabkan peningkatan aliran permukaan (run-off) yang menyebabkan terjadi peningkatan potensi bencana banjir. [7]

Mitra PKM merupakan bangunan sekolah menengah pertama negeri yang terletak di daerah Menteng, Jakarta Pusat merupakan daerah yang terletak di pusat kota, yang dikelilingi oleh kegiatan bisnis berupa perkantoran yang tepatnya berada di daerah Segitiga Emas Kuningan. Pada beberapa tahun terakhir wilayah di sekitar Mitra mengalami bencana banjir yang cukup besar, sehingga hal tersebut mengganggu proses belajar mengajar yang ada di SMP Negeri 8, Menteng, Jakarta Pusat. Selain banjir yang melanda pada musim penghujan, pada musim kemarau juga terjadi krisis air bersih yang melanda wilayah Mitra. Krisis air yang terjadi disebabkan oleh berkurangnya air tanah yang sedikit banyak diakibatkan oleh pemakaian air tanah yang berlebihan oleh bangunan-bangunan perkantoran yang ada di sekitar wilayah Mitra.

\section{METODE}

\subsection{Tahapan Kegiatan}

Secara garis besar tahapan kegiatan PKM dapat di kelompokkan menjadi tiga tahapan yaitu : tahap persiapan, tahap pelaksanaan kegiatan, tahap evaluasi dan pembuatan laporan hasil.

Penjelasan langkah-langkah kegiatan PKM sebagai berikut:

A. Tahap Persiapan

1. Studi Literatur

Pada tahap ini dilakukan pencarian referensi-referensi kegiatan yang berhubungan dengan kegiatan PKM yang akan dilaksanakan.

2. Penentuan Mitra

Pada tahap ini dilakukan pencarian Mitra tempat dilaksanakan kegiatan PKM sesuai dengan rumusan program dan rancangan kegian PKM

B. Tahap Pelaksanaan

1. Sosialisasi PKM

Pada Tahap ini dilakukan sosialisasi kegiatan PKM yang akan dilakukan pada Mitra yang telah ditunjuk

2. Pembuatan Sumur Resapan

Pada Tahap ini adalah pembuatan sumur resapan sesuai dengan gambar rencana pada proposal PKM

3. Tahap Evaluasi dan Pembuatan Laporan

Pada tahap ini merupakan evaluasi terhadap hasil sumur resapan mengacu pada situasi dan kondisi disaat proses kegiatan sosialisasi dan pembangunan sumur resapan dan kendalakendala yang dihadapi dan pembuatan laporan PKM.

\subsection{Sifat dan Bentuk Kegiatan}

Kegiatan Sosialisasi Pemanfaatan Air Hujan dengan Teknik Pembuatan Sumur Resapan untuk Menanggulangi Banjir/Genangan dan Konservasi Air Tanah ini dilakukan sesi sosialisasi dalam bentuk presentasi dan penjelasan materi yang diberikan kepada seluruh peserta kegiatan yang diikuti oleh 20 - 25 peserta. Materi yang diberikan antara lain berupa pengetahuan tentang isu-isu lingkungan global mengenai bencana banjir dan kekeringan yang sering menimpa kota-kota besar di Indonesia. Lalu dilanjutkan dengan pengetahuan mengenai pemanfaatan air hujan dengan pembuatan Sumur Resapan dan seperti apa konstruksi serta material dan bahan yang dapat digunakan dalam 
pembuatan Sumur Resapan. Pada sesi sosialisasi ini diakhiri dengan diskusi juga tanya jawab dengan peserta kegiatan.

Sesi selanjutkan dilakukan pada hari berikutnya. Pada sesi ini dilakukan proses pembuatan Sumur Resapan yang berlangsung selama 4 hari. Pelaksanaan pembuatan sumur resapan dilakukan oleh beberapa pekerja, dibantu oleh seluruh anggota tim PKM jurusan Teknik Sipil STT PLN dan Mitra. Jenis konstruksi sumur resapan yang digunakan pada wilayah Mitra adalah sumur dengan pasangan hebel pada dinding sumur sedangkan dasar sumur diisi dengan batu belah. Berikut merupakan desain Sumur Resapan yang dibangun pada wilayah Mitra.

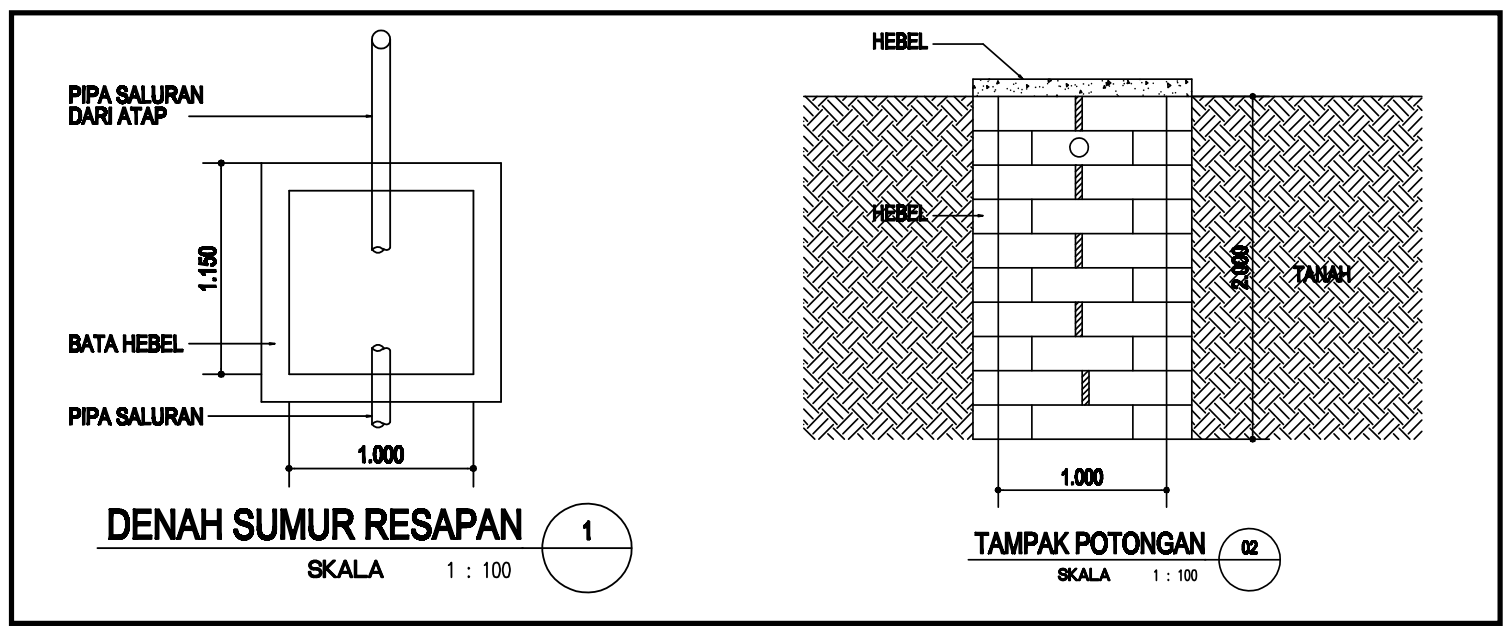

Gambar 1. Rencana Desain Sumur Resapan

\section{HASIL DAN PEMBAHASAN}

\subsection{Hasil}

Kegiatan sosialisasi pemanfaatan air hujan dengan teknik pembuatan sumur resapan dalam rangka untuk menumbuhkan sikap peduli terhadap lingkungan khususnya terhadap bahaya banjir/genangan dan bahaya kekeringan telah dilaksanakan.

Hasil dari kegiatan sosialisasi pemanfaatan air hujan dengan teknik pembuatan sumur resapan dan pembangunan sumur resapan yang merupakan tujuan dari kegiatan PKM ini, antara lain adalah:

1. Melalui kegiatan sosialisasi ini tim kegiatan PKM telah membantu dalam menyebarluaskan dan menerapkan hasil dari penelitian dan kajian kepada masyarakat sebagai upaya dalam memberdayakan dan meningkatkan kualitas hidup masyarakat dengan teknologi sumur resapan dalam menangani banjir dan konservasi air tanah.

2. Melalui kegiatan PKM ini merupakan bentuk kerjasama dan kemitraan dengan masyarakat sebagai perwujudan dari pengembangan kompetensi sosial di kalangan para dosen.

3. Melalui kegiatan PKM ini diharapkan dapat menumbuhkan kesadaran akan memenuhi kewajiban pembangunan Sumur Resapan yang sesuai dengan Peraturan Gubernur DKI Jakarta No. 20 tahun 2013 tentang Sumur Resapan.

4. Sumur Resapan yang telah dibangun untuk dapat dimanfaatkan sesuai dengan penggunaannya di SMPN 8, Menteng Jakarta Pusat, tepatnya untuk menampung air hujan yang berasal dari atap masjid di SMPN 8 sebanyak 1 buah sumur.

5. Seluruh civitas SMPN 8 memahami konsep sumber daya air tak terbarukan yang merupakan konsep teknologi pengisian air tanah (water recharge) dengan metode sumur resapan, sebagai siasat untuk pemenuhan kebutuhan air tanah di masa yang akan datang. 
6. Melalui kegiatan PKM ini diharapkan dapat mengembangkan kesadaran masyarakat mengenai bagaimana cara menanggulangi banjir pada skala kecil terlebih dahulu yaitu pada tingkat rumah tangga sampai ke tingkat yang lebih luas lagi, sekolah, bangunan-bangunan perkantoran, dan lain-lain. Juga meningkatkan kesadaran mengenai aktivitas menjaga kebersihan dengan tidak membuang sampah sembarangan apalagi di sungai-sungai yang dapat menimbulkan permasalahan banjir.

\subsection{Pembahasan}

Sesuai dengan rencana target luaran dengan pelaksanaan kegiatan sosialisasi pemanfaatan air hujan dengan teknik pembuatan sumur resapan diharapkan dapat membantu dalam meningkatkan pengetahuan dan kesadaran dalam penerapan IPTEK di kalangan masyarakat umum. Diawali dengan sosialisasi yang dilaksanakan di tingkat pendidikan dengan tujuan agar dapat berkembang luas informasinya sampai ke masyarakat umum di luar zona Pendidikan.

Acara sosialisasi pemanfaatan air hujan dengan Teknik pembuatan sumur resapan dilakukan pada hari Kamis, 14 Februari 2019 pada pukul 13.00 WIB sampai dengan selesai. Sedangkan pembangunan Sumur Resapan dilaksanakan 4 hari yaitu pada hari Jum'at, 14 - 17 Februari 2019. Sosialisasi dihadiri oleh tim PKM yang terdiri dari dosen Jurusan Teknik Sipil STT PLN Jakarta serta diikuti oleh 25 peserta yang terdiri dari Kepala Sekolah, Bapak/Ibu Guru peserta PokJa, siswasiswi pelajar di SMPN 8, Menteng Jakarta Pusat.
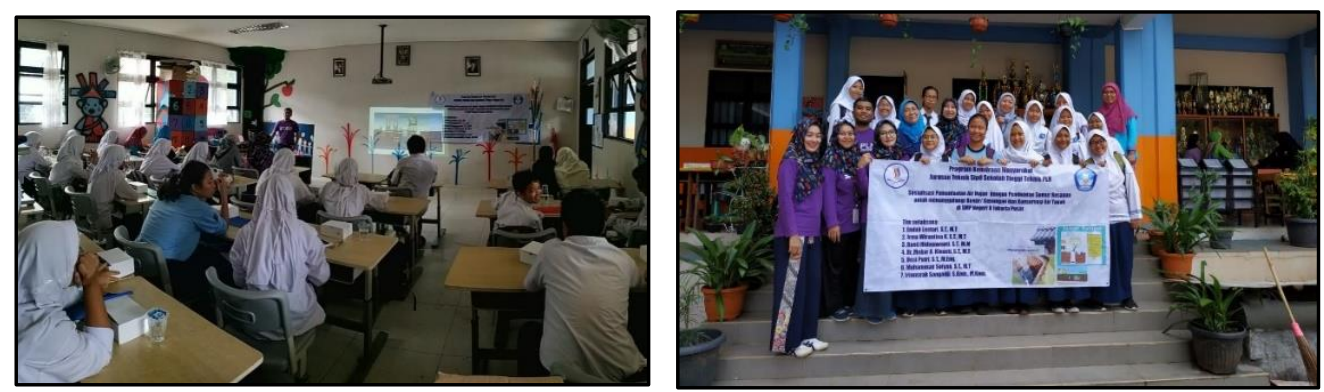

Gambar 2. Sosialisasi Pemfaatan air hujan dengan Teknik pembuatan sumur resapan

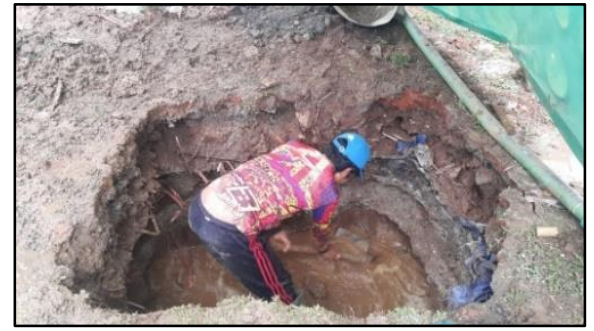

(a)

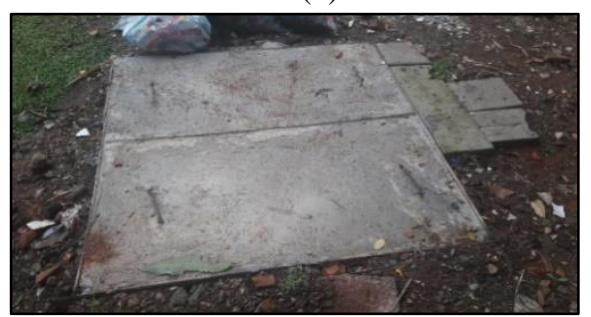

(c)

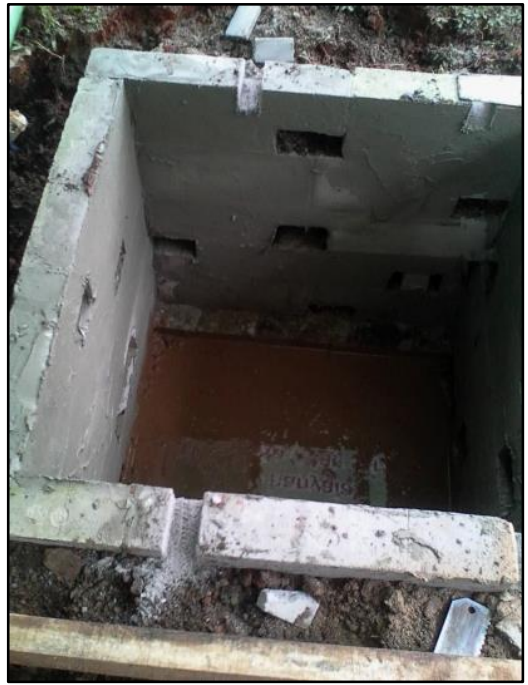

(b)

Gambar 3. Pembuatan sumur resapan. (a). penggalian lobang. (b). pemasangan dinding hebel. (c). pemasangan penutup sumur resapan 
Kegiatan PKM ini tentunya belum mampu menyelesaikan permasalahan Mitra dalam mengatasi banjir dan krisis air bersih di wilayah Mitra, namun setidaknya melalui kegiatan PKM ini Mitra lebih memahami bagaimana cara mengurangi jumlah air permukaan yang berasal dari air hujan. Dengan mengurangi jumlah air permukaan maka genangan bahkan banjir dapat dihindari. Kegiatan ini agar diharapkan Mitra dapat memahami cara kerja dari Sumur Resapan sebagai salah satu cara pengelolaan Sumber Daya Air khususnya air hujan. Dengan menggunakan metode memasukkan air hujan ke dalam tanah (water recharge) Mitra juga memahami bahwa dengan pembangunan Sumur Resapan merupakan salah satu cara dalam mengatasi kekurangan air tanah dan kekeringan di masa yang akan datang.

\section{KESIMPULAN}

Kesimpulan yang dapat diambil dari kegiatan Program Kemitraan Masyarakat dengan tema sosialisasi Pemanfaatan Air Hujan dengan Teknik Pembuatan Sumur Resapan untuk Menanggulangi Banjir/Genangan dan Konservasi Air Tanah, adalah:

1. Melalui kegiatan PKM ini diharapkan dapat menumbuhkan kesadaran akan memenuhi kewajiban pembangunan Sumur Resapan yang sesuai dengan Peraturan Gubernur DKI Jakarta No. 20 tahun 2013 tentang Sumur Resapan.

2. Melalui kegiatan sosialisasi PKM ini adalah memberikan kepada masyarakat kesadaran untuk membuka wawasan dalam pemanfaatan air hujan sebagai sumber daya air yang melimpah dengan pembuatan Sumur Resapan. Kegiatan dimaksudkan agar dapat menyadarkan masyarakat mengenai arti pentingnya melestarikan air tanah dengan cara memasukkan air ke dalam tanah (water recharge) untuk menghadapi musim kemarau.

3. Melalui kegiatan sosialisasi PKM ini adalah memberikan penjelasan kepada masyarakat melalui civitas Pendidikan mengenai penanggulangan banjir/genangan dalam skala kecil, yang bila diaplikasikan pada setiap bangunan/lahan kedap air akan menghasilkan dampak yang besar dalam mengatasi banjir.

4. Keberhasilan kegiatan PKM ini harus didukung oleh seluruh elemen masyarakat yaitu tim pelaksana PKM, institusi tim pelaksana PKM dan pihak Mitra guna meningkatkan rasa tanggung jawab terhadap lingkungan hidup sekitarnya dalam mengatasi bencana banjir dan kekeringan.

5. Berdasarkan evaluasi yang dilakukan terhadap kegiatan PKM ini menunjukkan perlunya diadakan kegiatan serupa dengan Mitra yang berbeda agar penyebarluasan informasi IPTEK lebih merata ke semua pihak dan elemen masyarakat sehingga mendapatkan hasil yang maksimal.

\section{SARAN}

Berdasarkan kendala dan uraian kegiatan di atas, saran-saran yang dapat diberikan antara lain adalah:

1. Agar mendapatkan hasil yang maksimal dalam pemanfaatan air hujan dalam menanggulangi banjir/genangan dan konservasi air tanah, hendaknya Mitra dapat melakukan pengembangan dengan membuat metode-metode lain selain sumur resapan di wilayah Mitra.

2. Untuk mengatasi cukup mahalnya material dan biaya pembuatan sumur resapan, maka perlu adanya penggantian material yang lebih terjangkau contohnya dengan menggunakan batu bata dan batako. Sehingga masyarakat umum dapat membangun sumur resapan pada lahan hunian masing-masing sesuai dengan persyaratan yang ada. 
3. Pemilihan Mitra selanjutnya diharapkan agar dapat mempertimbangkan kebutuhan Mitra, yaitu Mitra yang lokasinya berada pada daerah rawan banjir atau bahkan daerah bantaran sungai.

\section{UCAPAN TERIMA KASIH}

Ucapkan terima kasih atas pendanaan PKM ini oleh Sekolah Tinggi Teknik PLN Tahun Ajaran 2018/2019 dan juga semua pihak-pihak yang telah membantu terlaksananya kegiatan pengabdian pada masyarakat ini.

\section{DAFTAR PUSTAKA}

[1] M. Anggraeni and G. Prayitno, "The Effectiveness of Bio-pore as an Alternative Eco drainage Technology to Control Flooding in Malang City," J. Appl. Environ. Biol. ..., vol. 3, no. 2, pp. 23-28, 2013.

[2] H. T. Wijaya et al., "Manfaat sumur resapan dalam penanggulangan banjir di wilayah kelurahan penanggungan bagian selatan kota malang (," no. 03, 2002.

[3] E. Zimmermann, L. Bracalenti, R. Piacentini, and L. Inostroza, "Urban Flood Risk Reduction by Increasing Green Areas for Adaptation to Climate Change," Procedia Eng., vol. 161, pp. 2241-2246, 2016.

[4] A. Maryono, Memanen Air Hujan. Yogyakarta: Gajah Mada University Press, 2016.

[5] A. Stec and S. Kordana, "Analysis of profitability of rainwater harvesting, gray water recycling and drain water heat recovery systems," Resour. Conserv. Recycl., vol. 105, pp. 8494, 2015.

[6] Rofil, "Potensi dan Multifungsi Rainwater Harvesting (Pemanenan Air Hujan) di Sekolah bagi Infrastruktur Perkotaan," Biol. Educ. Conf., vol. 14, no. 1, pp. 247-251, 2017.

[7] A. Maryono, Menangani Banjir, Kekeringan, dan Lingkungan. Yogyakarta: Gadjah Mada University Press, 2014. 